\title{
Kajian Adaptive Neuro-Fuzzy Inference System (ANFIS) Dalam Memprediksi Penerimaan Mahasiswa Baru Pada Universitas Buana Perjuangan Karawang
}

\author{
Tatang Rohana \\ Universitas Buana Perjuangan Karawang \\ Teknik Informatika, Fakultas Teknik dan Ilmu Komputer UBP Karawang \\ tatang.rohana@ubpkarawang.ac.id
}

\begin{abstract}
The process of admitting new students is an annual routine activity that occurs in a university. This activity is the starting point of the process of searching for prospective new students who meet the criteria expected by the college. One of the colleges that holds new student admissions every year is Buana Perjuangan University, Karawang. There have been several studies that have been conducted on predictions of new students by other researchers, but the results have not been very satisfying, especially problems with the level of accuracy and error. Research on ANFIS studies to predict new students as a solution to the problem of accuracy. This study uses two ANFIS models, namely Backpropagation and Hybrid techniques. The application of the Adaptive Neuro-Fuzzy Inference System (ANFIS) model in the predictions of new students at Buana Perjuangan University, Karawang was successful. Based on the results of training, the Backpropagation technique has an error rate of $\mathbf{0 . 0 3 9 4}$ and the Hybrid technique has an error rate of 0.0662 . Based on the predictive accuracy value that has been done, the Backpropagation technique has an accuracy of 4.8 for the value of Mean Absolute Deviation (MAD) and $\mathbf{0 . 1 5 6 3 6 4 6 2 3}$ for the value of Mean Absolute Percentage Error (MAPE). Meanwhile, based on the Mean Absolute Deviation (MAD) value, the Backpropagation technique has a value of 0.5 and 0.09516671 for the Mean Absolute Percentage Error (MAPE) value. So it can be concluded that the Hybrid technique has a better level of accuracy than the Backpropation technique in predicting the number of new students at the University of Buana Perjuangan Karawang.
\end{abstract}

Keywords: ANFIS, Backpropagation, Hybrid, Prediction

\section{PENDAHULUAN}

Proses penerimaan mahasiswa baru merupakan kegiatan rutin tahunan yang terjadi dalam suatu perguruan tinggi. Kegiatan ini merupakan titik awal proses pencarian calon mahasiswa baru yang memenuhi kriteria yang diharapkan oleh perguruan tinggi tersebut. Salah satu perguruan tinggi yang menyelenggarakan penerimaan mahasiswa baru setiap tahunnya adalah Universitas Buana Perjuangan Karawang.

Universitas Buana Perjuangan Karawang adalah salah satu perguruan tinggi di wilayah Karawang yang perkembangannya sangat pesat. Hal ini terbukti dengan tingginya minat mahasiswa baru yang mendaftar dan dapat diterima di Universitas Buana Perjuangan Karawang. Hal ini tentu saja merupakan tantangan dan kesempatan yang baik bagi pihak universitas. Di sisi lain, stabilitas dan ketersediaan sarana dan prasarana kampus menjadi satu hal yang perlu diperhatikan oleh penyelenggara universitas. Pihak universitas tentu harus bisa memperhitungkan berapa jumlah mahasiswa baru yang diterima di Universitas Buana Perjuangan, hal ini penting bagi pihak penyelenggara sebagai bahan pengambilan keputusan terutama yang kaitannya dengan pengembangan kampus, sarana prasarana, maupun sumber daya yang mendukung proses belajar mengajar di lingkungan kampus.

Dalam penelitian ini, penulis menggunakan model ANFIS untuk memprediksi jumlah mahasiswa baru di Universitas Buana Perjuangan Karawang. Telah banyak penellitian yang dilakukan, degan menggunakan model Adaptive Neuro-Fuzzy Inference System (ANFIS) dalam sistem prediksi. Diantaranya, Penggunaan Artificial Neuro Fuzzy Inference Sistem (ANFIS) dalam Penentuan Status Aktivitas Gunung Merapi [5]; Penggunaan Jaringan Syaraf Tiruan Backpropagation Untuk Penerimaan Mahasiswa Baru Pada Jurusan Teknik Komputer Di Politeknik Negeri Sriwijaya [1]; Pengembangan Model Jaringan Syaraf Tiruan Untuk Memprediksi Jumlah Mahasiswa Baru Di PTS Surabaya [2]; Metode Adaptive Neuro Fuzzy Inference System (ANFIS) untuk Prediksi Tingkat Layanan Jalan [11], dan penelitian - penelitian lainnya. Diharapkan hasil dari penelitian ini dapat memberikan hasil akurasi dan tingkat kesalahan yang baik. Dalam penelitian ini, penulis mengangkat judul "Kajian Adaptive Neuro-Fuzzy Inference System (ANFIS) Dalam Memprediksi Penerimaan Mahasiswa Baru Pada Universitas Buana Perjuangan Karawang.

\section{A. Objek Penelitian}

\section{METODE PENELITIAN}

Obyek penelitian yang digunakan dalam penelitian ini, merupakan data yang diperoleh dari Panitia Penerimaan Mahasiswa Baru Universitas Buana Perjuangan Karawang yang kemudian divalidasi dengan Bagian Pusdatin. Data mahasiswa baru yang dijadikan sumber data dalam penelitian ini, diambil dari mahasiswa baru mulai tahun akademik 2015/2016 sampai dengan tahun akademik 2019/2020. 
Tabel 1. Mahasiswa Baru UBP Karawang Per Prodi Periode 2015 - 2019

\begin{tabular}{ccccccccccc}
\hline Tahun & PKn & PGSD & Hukum & Psik & Ak & Man & SI & IF & Far & TI \\
$2015 / 2026$ & 52 & 152 & 146 & 145 & 155 & 240 & 67 & 187 & 97 & 198 \\
$2016 / 2017$ & 54 & 165 & 131 & 150 & 179 & 356 & 56 & 178 & 109 & 243 \\
$2017 / 2018$ & 61 & 154 & 142 & 164 & 225 & 536 & 77 & 207 & 143 & 352 \\
$2018 / 2019$ & 40 & 139 & 156 & 162 & 190 & 490 & 75 & 231 & 140 & 356 \\
$2019 / 2020$ & 42 & 148 & 176 & 250 & 208 & 531 & 74 & 209 & 142 & 324 \\
\hline
\end{tabular}

Sumber : Pusdatin

Selanjutnya data tersebut akan diolah dengan proses preprocessing (pra proses) dengan cara embersihan data dan dan normalisasi, sebelum digunakan sebagai data analisis dalam penelitian ini. Hasil preprocessing tersebut, selanjutknya akan diproses dengan menggunakan metode Adaptive Neuro Fuzzy Inference System (ANFIS) sebagai metode untuk melakukan proses prediksi

\section{B. Pengumpulan Data}

Data adalah unit informasi yang direkam media yang dapat dibedakan dengan data lain, dapat dianalisis dan relevan dengan program tertentu. Pengumpulan data adalah prosedur yang sistematik dan standar untuk memperoleh data yang diperlukan. Untuk mengumpulkan data penelitian, penulis menggunakan metode wawancara. Untuk mendapatkan sumber data, penulis melakukan wawancara kepada Panitia Penerimaan Mahasiswa Baru (PPMB), yang kemudian divalidasi dengan Pusat Data (Pusdatin) Universitas Buana Perjuangan Karawang

\section{Analisa Data}

Teknik analisis data yang dilakukan adalah dengan membagi data menjadi dua, yaitu data training dan data testing. Pelatihan model menggunakan data training, sedangkan uji coba model menggunakan data testing. Hasil kesimpulan uji coba model akan diverifikasi dengan diagnosis pada data testing. Analisis data pada penelitian ini bertujuan untuk mengetahui seberapa akurat model Adaptive Neuro Fuzzy Inferences System (ANFIS) di Universitas Buana Perjuangan Karawang. Dalam memprediksi jumlah mahasiswa menggunakan metode dekomposisi nilai singular. Tahapan-tahapan analisis data ANFIS tersebut, dapat diihat pada gambar berikut:

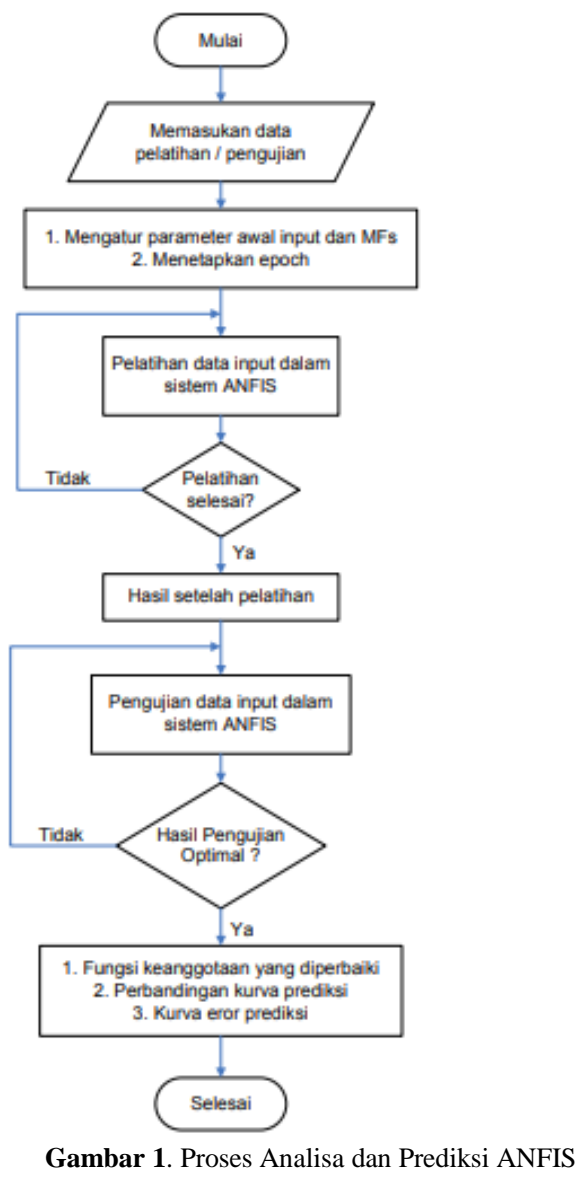

Data yang digunakan pada peneltian ini adalah data sekunder, yaitu data pendaptar dari mahasiswa baru yang diperoleh dari panitia penerimaan mahasiswa baru, dan mahasiswa aktif untuk tiap program studi yang diperoleh dari bagian Pusat Data dan

Informasi (PUSDATIN) Universitas Buana Perjuangan Karawang.

\section{Kerangka Pemikiran}


Permasalahan penerimaan mahasiswa baru di suatu perguruan tinggi merupakan masalah rutin yang terjadi setiap tahun akademik baru. Sehingga perlu penangan yang baik dalam pelaksanaannya. Informasi jumlah mahasiswa baru menjadi data penting bagi semua civitas kampus. Baik pimpinan, kemahasiswaan, akademik, sarana prasarana dan yang lainnya. Hal ini penting karena pihak kampus harus mempersiapkan segala sesuatunya berkatan dengan proses belajar mengajar. Sistem prediksi mahasiswa baru tentu sangat membantu pihak kampus dalam mempersiapkan kebutuahan - kebutuhan yang harus dipenuhi oleh semua civitas di suatu perguruan tinggi. Kerangka pemikiran dalam penelitian sistem prediksi ini, meliputi :

1. Jumlah mahasiswa baru dari tahun akademik 2015/2016 sampai dengan 2019/2020.

2. Data diperoleh dari Panitia Penerimaan Mahasiswa Baru dan dilengkapi juga dari Pusat Data UBP Karawang.

3. Preprocessing data (pemrosesan awal), pembersihan data (data cleaning) untuk menghilangkan kesalahan/error data dan transformasi data. .

4. Proses training dan pengujian data

5. Melakukan prediksi julah mahasiswa baru

6. Evaluasi tingkat akursi dengan model MAD dan MAPE

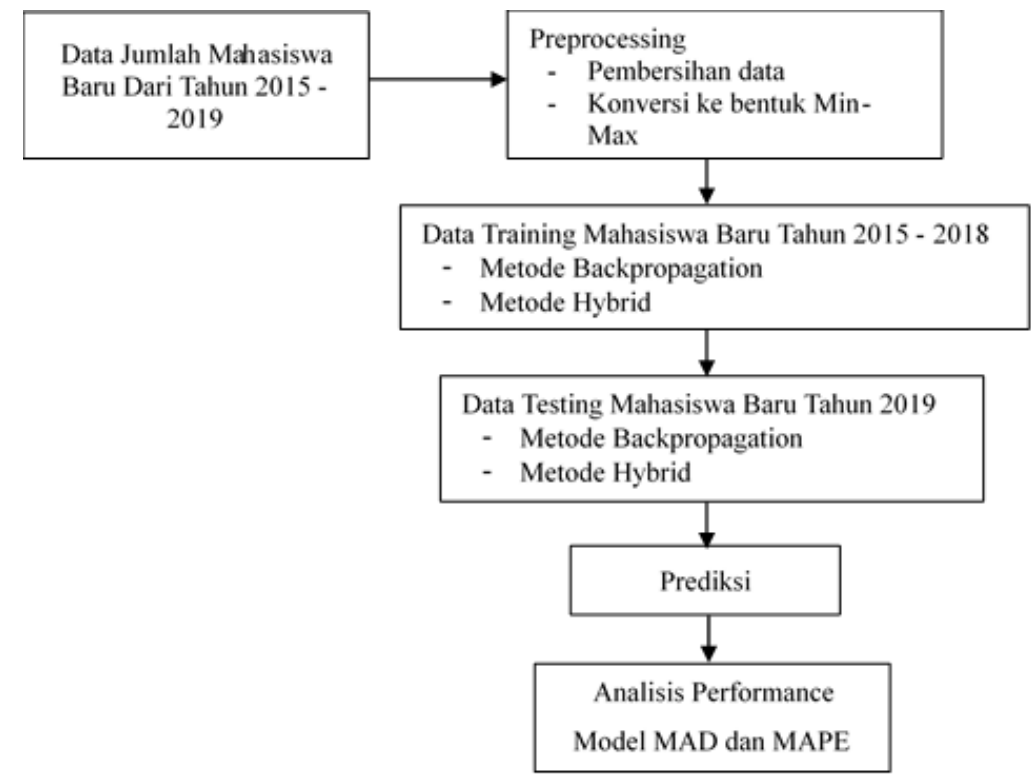

Gambar 2. Kerangka Pemikiran

\section{E. Waktu dan Tempat Penelitian}

1. Waktu Penelitian

Waktu yang digunakan peneliti untuk penelitian ini dilaksanakan sejak tanggal dikeluarkannya ijin penelitian dalam kurun waktu kurang lebih 5 (lima) bulan, 1 bulan pengumpulan data, 1 bulan analisa data, 3 bulan pengolahan data dan laporan penelitian.

2. Tempat Penelitian

Tempat pelaksanaan penelitian ini adalah di Universitas Buana Perjuangan Karawang yang beralamat di Jalan Ronggo Waluyo Sirnabaya, Puseurjaya, Kec. Telukjambe Tim., Kabupaten Karawang, Jawa Barat 41361

3. Instrumen Penelitian

Instrumen penelitian ini diperlukan agar penelitian dapat berjalan dengan lancer dan baik. Instruem tersebut terdiri dari perangkat lunak dan perangkat keras.

4. Kebutuhan Perangkat Lunak

Perangkat lunak yang dibutuhkan dalam penelitian ini adalah :

a. Microsoft Windows 7 sebagai Operating System notebook

b. Microsoft Excel 2013 sebagai media penulisan datasheet.

c. Matlabs versi 2010b, software yang digunakan untuk melihat hasil akurasi dari algoritma yang digunakan untuk mengolah data set penelitian.

Kebutuhan Perangkat Keras

Perangkat Keras yang dibutuhkan dalam penelitian ini adalah notebook dengan spesifikasi berikut ini :

a. Prosesor Core I3

b. RAM 2 GB

c. Hardisk $500 \mathrm{~GB}$ 


\section{F. Diagram Alir Penelitian}

Diagram alir penelitian dapat dijelaskan berdasarkan gambar 3 di bawah ini.

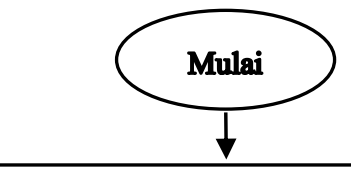

Pengumpulan Data

- Studi Pustaka/Litelatur

- Observasi/Wawancara
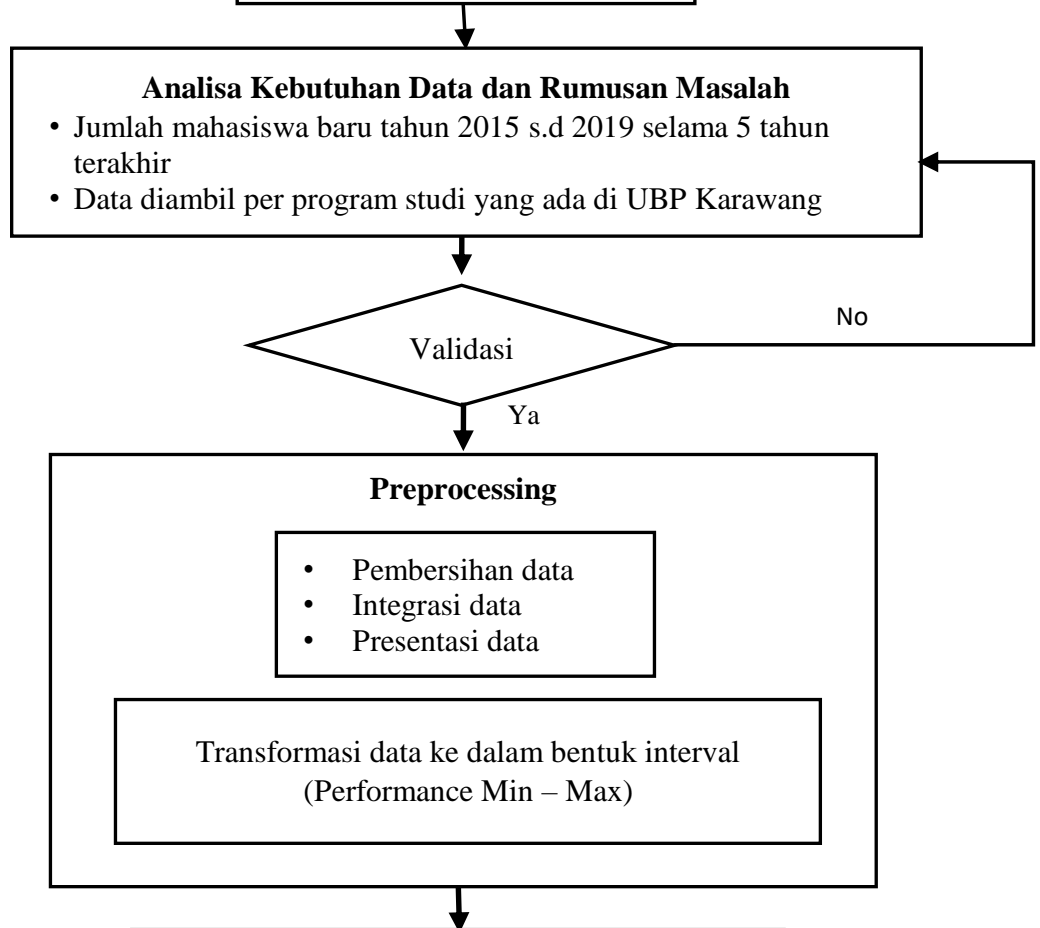

\section{Proses ANFIS}

- Mengajukan data pelatihan/pengujian

- Menentukan nilai parameter input Mfs

- Menentukan Epoch (iterasi)

- Pelatihan dan pengujian data input ANFIS

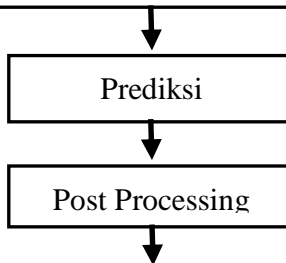

\section{Analisa dan Pembahasan}

- Membandingkan hasil prediksi menggunakan Backpropagation dan Hybrid

- Pengujian kehandalan jaringan menggunakan indeks statistik Mean Absolute Deviation (MAD) dan Mean Absolute Precentage Error (MAPE).

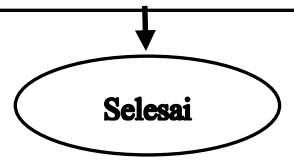

Gambar 3. Diagram Alir Penelitian 
1. Pengumpulan Data dan Menentukan Objek Penelitian

Penelitian dilakukan secara berkala dalam kurun waktu kurang lebih 5 bulan (Desember 2019 - Mei 2020). Objek data yang akan digunakan dalam penelitian adalah data penerimaan mahasiswa baru antara tahun 2015-2019. Selain data dari Universitas Buana Perjuangan, digunakan juga data berupa materi-materi penunjang atau jurnal untuk membantu melakukan penelitian. Beberapa jurnal diambil dari kumpulan jurnal-jurnal resmi yang dapat diambil dari situs resmi yang beredar di internet.

2. Analisa Kebutuhan Data Penelitian

Untuk melengkapi referensi penelitian ini, ditunjang juga data berupa materi-materi penunjang atau jurnal untuk membantu melakukan penelitian. Beberapa jurnal diambil dari kumpulan jurnal-jurnal resmi yang dapat diambil dari situs resmi yang beredar di internet

3. Merumusan Masalah Penelitian

Dalam penelitian ini, dirumuskan masalah yang berkaitan dengan penerimaan mahasiswa baru yang meliputi :

a) Bagaimana menerapkan metode Adaptive Neuro-Fuzzy Inference System (ANFIS) dalam mengambil keputusan untuk memprediksi jumlah mahasiswa baru yang diterima di Universitas Buana Perjuangan Karawang.

b) Bagaimana tingkat akurasi dan sebaran data terbentuk dalam metode Adaptive Neuro-Fuzzy Inference System (ANFIS) yang dihasilkan dari hasil uji data yang dilakukan.

c) Bagaimana cara menganalisa hasil data uji dan trainning dari metode Adaptive Neuro-Fuzzy Inference System (ANFIS).

4. Validasi Data Penelitian

Validasi data penting dilakukan dalam penelitian ini. Karena langkah pemeriksaan untuk memastikan bahwa data yang digunakan telah sesuai dengan kriteria yang ditetapkan dalam penelitian, dan dapat dijelaskan sumber dan kebenaran datanya.

5. Pre - Processing

Pada tahapan ini, data penelitian dinormalisasi terlebih dahulu dengan tujuan menghindari data yang tidak akurat dan inkonsisten. Selanjutnya dilakukan proses transformasi data ke dalam bentuk interval, yaitu model performance min $\max$.

\section{Proses ANFIS}

Arsistektur sistem ANFIS yang digunakan dalam penelitian ini memiliki 5 lapisan. Lapisan pertama adalah lapisan adaptif untuk perhitungan derajat keanggotaan, lapisan kedua untuk perhitungan firing strength, lapisan ketiga untuk perhitungan normalisasi firing strength, lapisan keempat adalah juga merapakan lapisan adaptif untuk perhitungan parameter konsekuen dan lapisan kelima untuk perhitungan output jaringan.

\section{HASIL PENELITIAN DAN PEMBAHASAN}

\section{A. Preprocessing Data}

Langkah awal yang dilakukan pada data penelitian ini, adalah melakukan pra pengolahan data terhadap jumlah mahasiswa baru yang diterima di Universitas Buana Perjuanga Karawang periode tahun akademik 2015/ 2016 samapai dengan 2019/2020. Hal ini perlu dilakukan karena data yang digunakan dalam prosesnya tidak selalu ideal untuk diproses. Terkadang pada data tersebut terdapat berbagai permasalahan yang dapat mengganggu hasil dari proses itu sendiri seperi diantaranya adalah missing value, data redundant, outliers, ataupun format data yang tidak sesuai dengan sistem. Proses pra pengolahan data ini meliputi beberapa tahap, yaitu meliputi pembersihan data dan normalisasi data.

1. Pembersihan data (Data cleaning)

Pembersihan data dilakukan untuk menghilangkan data - data yang tidak efisien dan mengandung kesalahan. Dalam proses ini, data dibersihkan dengan menggunakan aplikasi Rapidminer.

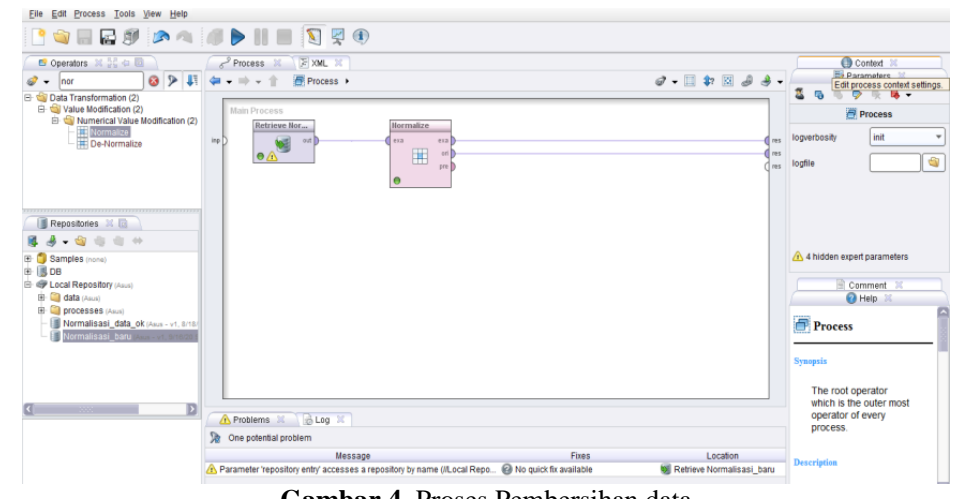

Gambar 4. Proses Pembersihan data 


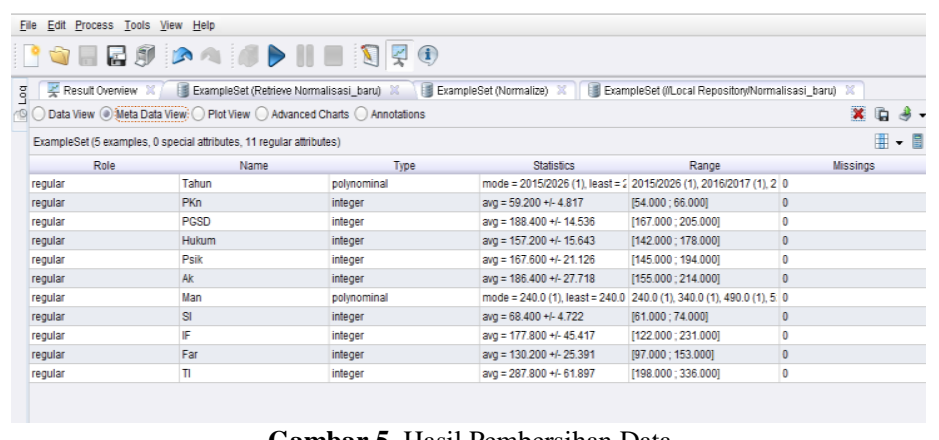

Gambar 5. Hasil Pembersihan Data

Dari proses pembersihan data di atas, menunjukan bahwa tidak ada kesalahan atau missing pada data yang digunakan dalam penelitian ini.

\section{Normalisasi Data}

Sebelum data input dimasukkan kedalam jaringan terlebih dahulu data ditransformasi kedalam bentuk data interval (normalisasi). Data-data tersebut dinormalisasi sehingga menjadi data yang berada dalam selang/rentang [0,1]. Normalisasi menggunakan rumus Min - Max (Han, Kamber, dan Pei, 2012).

$$
\mathrm{Z}=\frac{X-X \min }{X \max -X \min } \cdot(B \max -B \min )+B \min
$$

Misalkan data input $\mathrm{X}$ dengan jumlah data $\mathrm{n}, \mathrm{X}_{1}, \mathrm{X}_{2}, \ldots, \mathrm{X}_{\mathrm{n}}$. dengan :

$\begin{array}{ll}\mathrm{X} & =\text { data input } \\ \mathrm{X}_{\min } & =\text { data } \mathrm{X} \text { minimum } \\ \mathrm{X}_{\max } & =\text { data } \mathrm{X} \text { maksimum } \\ \mathrm{B}_{\max } & \text { = batas atas interval } \\ \mathrm{B}_{\min } & \text { = batas bawah interval }\end{array}$

Tujuan dari normalisasi adalah menyamakan selang dari nilai-nilai tiap data sehingga setiap data memiliki peran yang proporsional dalam setiap proses. Untuk memudahkan dalam proses konversi, nama Program Studi di rubah menjadi variabel X. Yaitu $\mathrm{X}_{1}, \mathrm{X}_{2}, \ldots . \mathrm{X}_{10}$

Tabel 2. Data Jumlah Mahasiswa Baru

\begin{tabular}{ccccccccccc}
\hline Tahun & $\mathrm{X}_{1}$ & $\mathrm{X}_{2}$ & $\mathrm{X}_{3}$ & $\mathrm{X}_{4}$ & $\mathrm{X}_{5}$ & $\mathrm{X}_{6}$ & $\mathrm{X}_{7}$ & $\mathrm{X}_{8}$ & $\mathrm{X}_{9}$ & $\mathrm{X}_{10}$ \\
$2015 / 2026$ & 52 & 152 & 146 & 145 & 155 & 240 & 67 & 187 & 97 & 198 \\
$2016 / 2017$ & 54 & 165 & 131 & 150 & 179 & 356 & 56 & 178 & 109 & 243 \\
$2017 / 2018$ & 61 & 154 & 142 & 164 & 225 & 536 & 77 & 207 & 143 & 352 \\
$2018 / 2019$ & 40 & 139 & 156 & 162 & 190 & 490 & 75 & 231 & 140 & 356 \\
$2019 / 2020$ & 42 & 148 & 176 & 250 & 208 & 531 & 74 & 209 & 142 & 324 \\
\hline
\end{tabular}

Menjadi data interval $[0,1]$

Tabel 3. Konversi Data Menjadi Min - Max

\begin{tabular}{ccccccccccc}
\hline Tahun & $\mathrm{X}_{1}$ & $\mathrm{X}_{2}$ & $\mathrm{X}_{3}$ & $\mathrm{X}_{4}$ & $\mathrm{X}_{5}$ & $\mathrm{X}_{6}$ & $\mathrm{X}_{7}$ & $\mathrm{X}_{8}$ & $\mathrm{X}_{9}$ & $\mathrm{X}_{10}$ \\
\hline $2015 / 2016$ & 0,572 & 0,5 & 0,333 & 0 & 0 & 0 & 0,523 & 0,169 & 0 & 0 \\
$2016 / 2017$ & 0,666 & 1 & 0 & 0,047 & 0,24 & 0,391 & 0 & 0 & 0,26 & 0,284 \\
$2017 / 2018$ & 1 & 0,576 & 0,244 & 0,18 & 1 & 1 & 1 & 0,547 & 1 & 0,974 \\
$2018 / 2019$ & 0 & 0 & 0,555 & 0,161 & 0,5 & 0,844 & 0,904 & 1 & 0,934 & 1 \\
$2019 / 2020$ & 0,095 & 0,346 & 1 & 1 & 0,757 & 0,983 & 0,857 & 0,584 & 0,978 & 0,797 \\
\hline
\end{tabular}

\section{B. Pengujian Hipotesis}

1. Proses Pelatihan Data

Data yang sudah dinormalisasi ke dalam bentuk Min - Max, selanjutnya dijadikan sumber data untuk proses trainig (pelatihan) dan testing (data uji) pada proses analisis ANFIS. Untuk proses analisis ANFIS, data dibagi menjadi dua bagian, yaitu data training dan data testing. Data mahasiswa baru tahun 2015 sampai dengan tahun 2018 dijadikan data training (latih), sedangkan data mahasiswa baru tahun 2019 dijadikan data testing (uji)

Tabel 4. Data Training

\begin{tabular}{cccccccccc}
\hline $\mathrm{X}_{1}$ & $\mathrm{X}_{2}$ & $\mathrm{X}_{3}$ & $\mathrm{X}_{4}$ & $\mathrm{X}_{5}$ & $\mathrm{X}_{6}$ & $\mathrm{X}_{7}$ & $\mathrm{X}_{8}$ & $\mathrm{X}_{9}$ & $\mathrm{X}_{10}$ \\
\hline
\end{tabular}




\begin{tabular}{cccccccccc}
0,572 & 0,5 & 0,333 & 0 & 0 & 0 & 0,523 & 0,169 & 0 & 0 \\
0,666 & 1 & 0 & 0,047 & 0,24 & 0,391 & 0 & 0 & 0,26 & 0,284 \\
1 & 0,576 & 0,244 & 0,18 & 1 & 1 & 1 & 0,547 & 1 & 0,974 \\
0 & 0 & 0,555 & 0,161 & 0,5 & 0,844 & 0,904 & 1 & 0,934 & 1 \\
\hline
\end{tabular}

Tabel 5. Data Testing

\begin{tabular}{cccccccccc}
\hline $\mathrm{X}_{1}$ & $\mathrm{X}_{2}$ & $\mathrm{X}_{3}$ & $\mathrm{X}_{4}$ & $\mathrm{X}_{5}$ & $\mathrm{X}_{6}$ & $\mathrm{X}_{7}$ & $\mathrm{X}_{8}$ & $\mathrm{X}_{9}$ & $\mathrm{X}_{10}$ \\
\hline 0,095 & 0,346 & 1 & 1 & 0,757 & 0,983 & 0,857 & 0,584 & 0,978 & 0,797 \\
\hline
\end{tabular}

Proses training (pelatihan) dengan model Adaptive Neuro-Fuzzy Inference System (ANFIS) dilakukan dengan menggunakan tool Matlab R2010. Analisa data untuk prediksi ini, memakai dua model Adaptive Neuro-Fuzzy Inference System (ANFIS), yaitu teknik Backpropagation dan Hybrid. Sehingga proses pelatihan dan pengujiannya juga berdasarkan kedua teknik tersebut.

a. Pelatihan Data Teknik Backpropagation

Data yang ada pada tabel 4.3, yaitu data mahasiswa baru dijadikan data traning (pelatihan). Proses pelatihan terdiri dari 20 epoch (iterasi) dengan toleransi kesalahan sebesar 0,001. Proses pelatihan teknik Backpropagation dengan matlab menghasilkan informasi sebagai berikut :

ANFIS info:

Number of nodes: 182

Number of linear parameters: 80

Number of nonlinear parameters: 152

Total number of parameters: 232

Number of training data pairs: 4

Number of checking data pairs: 0

Number of fuzzy rules: 4

Dari hasil pelatihan data dengan teknik Backpropagation tingkat kesalahan yang diperoleh sebesar 0,0394.

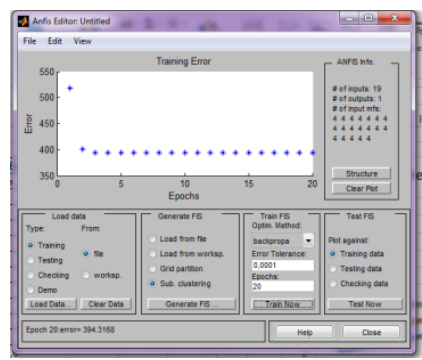

Gambar 6. Proses Pelatihan Teknik Backpropagation

Dari pelatihan teknik Backpropagation di atas, dihasilkan tingkat kesalahan sebesar 0,0394 dengan toleransi kesalahan sebesar 0,001 dengan iterasi 20 kali. Dari nilai kesalahan ini, maka tingkat kenaikan dan penurunan prediksi mahasiswa dengan teknik Backpropagation sebesar 3,94\%

b. Pelatihan Data Teknik Hybrid

Dengan cara yang sama, pelatihan berikutnya dilakukan dengan menggunakan teknik Hybrid. Proses pelatihan dilakukan sebanyak 20 kali dengan toleransi kesalahan sebesar 0,001. Proses pelatihannya dapat dilihat pada gambar berikut :

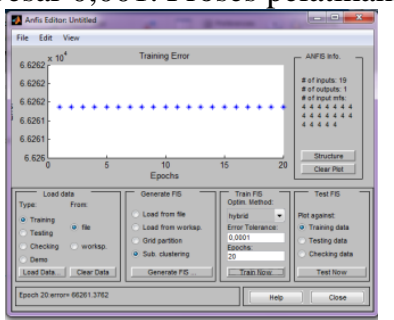

ANFIS info:

Gambar 7. Proses Pelatihan Teknik Hybrid

Number of nodes: 182

Number of linear parameters: 80

Number of nonlinear parameters: 152

Total number of parameters: 232

Number of training data pairs: 4

Number of checking data pairs: 0

Number of fuzzy rules: 4

Epoch 20

Error tolerance 0,001 
Berdasarkan hasil pelatihan dengan teknik Hybrid, maka dihasilkan tingkat kesalahan sebesar 0,0662. Dengan nilai kesalahan tersebut, maka nilai prediksi kenaikan dan penurunan mahasiswa baru dengan teknik Hybrid sebesar 6,62 \%

2. Proses Pengujian Data

Proses berikutnya adalah proses pngujian atau data testing. Pengujian ini merupakan penerapan hasil pelatihan data terhadap prediksi mahasiswa baru. Data yang digunakan dalam proses ini adalah jumlah mahasiswa baru tahun 2019, datanya dapat dilihat pada tabel berikut :

Tabel 6. Data Uji

\begin{tabular}{cccccccccc}
\hline $\mathrm{X}_{1}$ & $\mathrm{X}_{2}$ & $\mathrm{X}_{3}$ & $\mathrm{X}_{4}$ & $\mathrm{X}_{5}$ & $\mathrm{X}_{6}$ & $\mathrm{X}_{7}$ & $\mathrm{X}_{8}$ & $\mathrm{X}_{9}$ & $\mathrm{X}_{10}$ \\
\hline 0,095 & 0,346 & 1 & 1 & 0,757 & 0,983 & 0,857 & 0,584 & 0,978 & 0,797 \\
42 & 148 & 176 & 250 & 208 & 531 & 74 & 209 & 142 & 324 \\
\hline
\end{tabular}

Dari proses training atau pelatihan di atas, diperoleh nilai prediksi dengan tenik Backpropagation sebesar 0,0394 sedangkan dengan teknik Hybrid sebesar 0,0662.

A. Pengujian Data Backpropagation

Hasil pengujian dengan parameter - parameter yang diperoleh dari proses pelatihan data dengan tingkat kesalahan sebesar 0,0394 untuk teknik Backpropagation, maka diperoleh hasil prediksi dan error mahasiswa baru untuk tahun 2019.

Tabel 7. Hasil Prediksi dan Error Teknik Backpropagation

\begin{tabular}{clccc}
\hline No & Prodi & Data Aktual & $\begin{array}{c}\text { Prediksi } \\
\text { Backpropagation }\end{array}$ & Error \\
\hline 1 & PKn & 42 & 42 & 0 \\
2 & PGSD & 148 & 144 & 4 \\
3 & Hukum & 176 & 162 & 14 \\
4 & Psik & 250 & 168 & 82 \\
5 & Ak & 208 & 197 & 11 \\
6 & Man & 531 & 509 & 22 \\
7 & SI & 74 & 78 & 4 \\
8 & IF & 209 & 240 & 31 \\
9 & Far & 142 & 146 & 4 \\
10 & TI & 324 & 370 & 46 \\
\hline
\end{tabular}

Secara grafik dapat dilihat pada gambar di bawah ini :

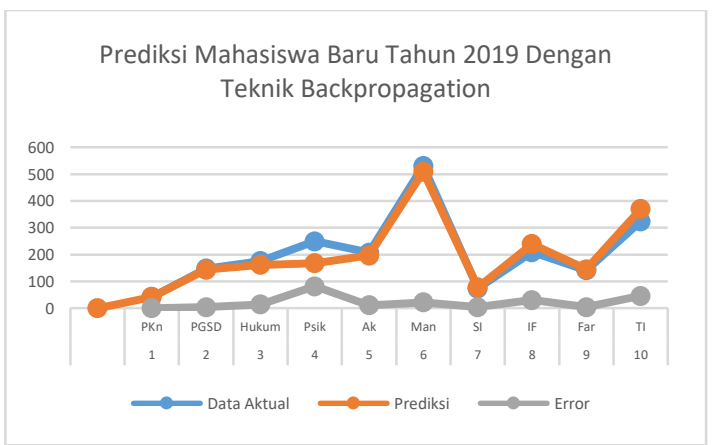

Gambar 8. Grafik Prediksi Teknik Backpropagation

B. Pengujian Data Hybrid

Sedangkan dari proses pelatihan data dengan tingkat kesalahan sebesar 0,0662 untuk teknik Hybrid, maka diperoleh hasil prediksi dan error mahasiswa baru untuk tahun 2019 sebagai berikut :

Tabel 8. Hasil Prediksi dan Error Teknik Hybrid

\begin{tabular}{clccc}
\hline No & Prodi & Data Aktual & $\begin{array}{c}\text { Prediksi 2019 } \\
\text { Hybrid }\end{array}$ & Error \\
\hline 1 & PKn & 42 & 43 & 1 \\
2 & PGSD & 148 & 148 & 0 \\
3 & Hukum & 176 & 166 & 10 \\
4 & Psik & 250 & 173 & 77 \\
5 & Ak & 208 & 203 & 5 \\
6 & Man & 531 & 522 & 9 \\
7 & SI & 74 & 80 & 6 \\
8 & IF & 209 & 246 & 37 \\
9 & Far & 142 & 149 & 7
\end{tabular}




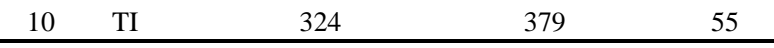

Grafiknya sebagai berikut :

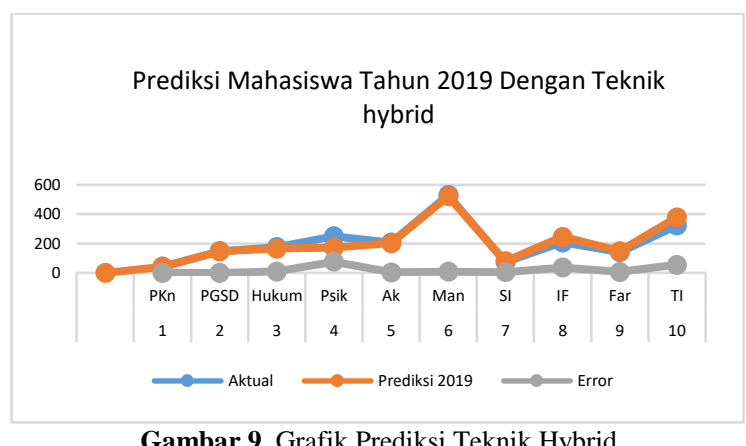

\section{Analisis Dan Pembahasan}

Model yang digunakan dalam penelitian ini adalah Adaptive Neuro Fuzzy Inference System (ANFIS). Sedangkan teknik yang dipakai dalam Fuzzy Inference System (FIS) - nya adalah Teknik Backpropagation dan Hybrid. Untuk mengukur tingkat akurasi kedua teknik tersebut, maka harus dicari tingkat kesalahan (error) dari masing - masing teknik tersebut. (Hanke \& Wichern, 2005) mengatakan bahwa di dalam teknik forecasting yang menggunakan data kuantitatif sering terdapat data berupa runtun waktu tertentu. Yang dimana biasa terdapat error / kesalahan yang dilakukan oleh teknik forecasting. Oleh sebab itu dibutuhkan metode untuk mengukur seberapa besar error / kesalahan yang dapat dihasilkan oleh metode - metode forecasting untuk dipertimbangkan kembali sebelum membuat keputusan. Adapula kegunaan dari metode mengukur error forecasting ini adalah :

- Mengkomparasi akurasi dari 2 (atau lebih) metode forecasting yang dipakai.

- Mengukur realibilitas dan manfaat dari metode forecasting yang dipakai.

- Mencari metode forecasting yang paling optimal bagi organisasi atau perusahaan.

Untuk mengukur tingkat akurasi teknik Backpropagation dan Hybrid, maka digunakan metode Mean absolute deviation (MAD) dan Mean absolute percentage error(MAPE). Tingkat akurasi yang baik, adalah jika tingkat kesalahannya (error) lebih kecil dibanding dengan yang lainnya.

1. Mean Absolute Deviation (MAD)

Mean absolute deviation mengukur akurasi dari prediksi (forecast) dengan membuat sama rata dari besarnya kesalahan perkiraan, yang dimana setiap prediksi memiliki nilai absolut untuk setiap errornya.

Rumus yang dipakai untuk menghitung MAD adalah :

$M A D=\frac{1}{n} \sum_{t=1}^{n}\left|Y_{t}-\hat{P}_{t}\right|$

Keterangan :

$\mathrm{Y}_{\mathrm{t}} \quad=$ nilai aktual pada periode $\mathrm{t}$

$\ddot{Y}_{\mathrm{t}} \quad=$ nilai forcast pada periode $\mathrm{t}$

$\mathrm{n} \quad=$ jumlah periode data

Dari hasil pengukuran tingkat akurasi teknik Backpropagation dan Hybrid yang sudah dilakukan dengan metode Mean Absolute Deviation (MAD), maka didapatkan nilai sebagai berikut :

Tabel 9. Mean Absolute Deviation (MAD) Prediksi Backpropagation

\begin{tabular}{ccc}
\hline Jumlah Aktual & Prediksi Backpropagation & $\mathrm{Y}_{1-\hat{y}_{\mathrm{t}}}$ \\
\hline 42 & 42 & -1 \\
148 & 144 & 0 \\
176 & 162 & 10 \\
250 & 168 & 77 \\
208 & 197 & 5 \\
531 & 509 & 9 \\
74 & 78 & -6 \\
209 & 240 & -37 \\
142 & 146 & -7 \\
324 & 370 & -55 \\
& Jumlah Deviasi Absolut & 5 \\
& MAD & 0,5 \\
\hline
\end{tabular}

Dari tabel di atas, maka nilai Mean Absolute Deviation (MAD) yang diperoleh sebesar 4,8, dan untuk jumlah deviasi absolut sebesar 48. Sedangkan untuk teknik Hybrid, maka nilai Mean Absolute Deviation (MAD) yang diperoleh sebesar 0,5 dan jumlah deviasi absolutnya sebesar 5. Selengkapnya dapat dilihat pada tabel.9.

Tabel 10. Mean Absolute Deviation (MAD) Prediksi Hybrid

\begin{tabular}{lll}
\hline Jumlah Aktual & Prediksi Hybrid & $\mathrm{Y}_{1-\hat{y}_{\mathrm{t}}}$ \\
\hline
\end{tabular}




\begin{tabular}{ccc}
\hline 42 & 43 & 0 \\
148 & 148 & 4 \\
176 & 166 & 14 \\
250 & 173 & 82 \\
208 & 203 & 11 \\
531 & 522 & 22 \\
74 & 80 & -4 \\
209 & 246 & -31 \\
142 & 149 & -4 \\
324 & 379 & -46 \\
& Jumlah Deviasi Absolut & 48 \\
& MAD & 4,8 \\
\hline
\end{tabular}

\section{Mean absolute percentage error (MAPE)}

Mean absolute percentage error dihitung dengan cara mencari error/kesalahan absolut di setiap periode, yang dimana dibagi dengan nilai observasi yang aktual pada periode itu, dan dibuat rata - rata dari absolute percentage error tersebut. Rumus yang dipakai untuk menghitung MAPE adalah :

$$
\sum_{t=1}^{n} \frac{Y t-Y^{\prime} t}{Y t} \times 100
$$

Keterangan :

n : Jumlah periode data

$\mathrm{Y}_{\mathrm{t}} \quad$ : nilai aktual pada periode $\mathrm{t}$

$\mathrm{Y}_{\mathrm{t}} \quad$ : nilai ramalan pada periode $\mathrm{t}$

Berdasarkan hasil perhitungan Mean absolute percentage error (MAPE) untuk teknik Backpropagation, diperoleh nilai kesalahan sebesar 1,56365 dengan nilai MAPE 0,1563647. Dengan nilai kessalahan prediksi sebesar $15,6 \%$.

Tabel 11. Nilai Mean Absolute Percentage Error Prediksi Backpropagation

\begin{tabular}{ccc}
\hline Jumlah Aktual & Prediksi Backpropagation & $\mathrm{Y}_{1-\hat{y}_{\mathrm{t}}}$ \\
\hline 42 & 42 & 0 \\
148 & 144 & 0,02703 \\
176 & 162 & 0,07955 \\
250 & 168 & 0,328 \\
208 & 197 & 0,05288 \\
531 & 509 & 0,04143 \\
74 & 78 & $-0,05405$ \\
209 & 240 & $-0,14833$ \\
142 & 146 & $-0,02817$ \\
324 & 370 & $-0,14198$ \\
\multicolumn{2}{c}{ Jumlah Deviasi Absolut } & 1,56363 \\
& MAPE & 0 \\
\hline
\end{tabular}

Sedangkan untuk teknik Hybrid, diperoleh nilai kesalaha sebesar 0,95167162 dengan nilai MAPE 0,09516671. Degan demikian maka nilai kesalahan prediksi dengan teknik hybrid sebesar 9,52\%.

Tabel 12. Nilai Mean Absolute Percentage Error Prediksi Hybrid

\begin{tabular}{ccc}
\hline Jumlah Aktual & Prediksi Backpropagation & $\mathrm{Y}_{1-\hat{y}_{\mathrm{t}}}$ \\
\hline 42 & 43 & $-0,023809$ \\
148 & 148 & 0 \\
176 & 166 & 0,056818 \\
250 & 173 & 0,308 \\
208 & 203 & 0,024038 \\
531 & 522 & 0,016949 \\
74 & 80 & $-0,081081$ \\
209 & 246 & $-0,177033$ \\
142 & 149 & $-0,0492957$ \\
324 & 379 & $-0,169753$ \\
\multicolumn{2}{r}{} \\
\hline
\end{tabular}

Dengan hasil pengujian ini, maka dapat disimpulkan bahwa prediksi mahasiswa baru Universitas Buana Perjuangan Karawang dengan model Adaptive Neuro-Fuzzy Inference System (ANFIS) dapat digunakan dengan baik. Hal ini dibuktikan dengan hasil training (pelatihan) teknik Backpropagation memiliki tingkat kesalahan (Error rate) sebesar 0,0394, sedangkan teknik Hybrid memiliki tingkat kesalahan sebesar 0,0662. Kemudian berdasarkan perhitungan nilai akurasi dalam memprediksi, teknik Backpropagation memiliki akurasi 4,8 untuk nilai Mean Absolute Deviation (MAD) dan 0,156364623 untuk nilai Mean Absolute Percentage Error (MAPE). Sedangkan berdasarkan nilai Mean Absolute Deviation (MAD), teknik Backpropagation memiliki nilai 0,5 dan 0,09516671 untuk nilai Mean Absolute Percentage Error (MAPE). Kalau dibandingkan akurasinya, maka teknik Hybrid lebih akurat dibandingkan teknik Backpropagation, karena memiliki nilai akurasi kesalahan yang lebih kecil. 


\section{KESIMPULAN DAN SARAN}

\section{A. Kesimpulan}

Dari hasil penelitian dan pegujian yang sudah dilakukan tentang Kajian Adaptive Neuro-Fuzzy Inference System (ANFIS) Dalam Memprediksi Mahasiswa Baru Pada Universitas Buana Perjuangan Karawang, maka dapat disimpulkan hal sebagai berikut :

1. Penerapan model Adaptive Neuro-Fuzzy Inference System (ANFIS) dalam prediksi mahasiswa baru di Universitas Buana Perjuangan Karawang berhasil dengan baik. Berdasarkan hasil training teknik Backpropagation memiliki error rate sebesar 0,0394 dan teknik Hybrid memiliki error rate sebesar 0,0662.

2. Berdasarkan nilai akurasi prediksi yang sudah dilakukan, teknik Backpropagation memiliki akurasi 4,8 untuk nilai Mean Absolute Deviation (MAD) dan 0,156364623 untuk nilai Mean Absolute Percentage Error (MAPE). Sedangkan berdasarkan nilai Mean Absolute Deviation (MAD), teknik Backpropagation memiliki nilai 0,5 dan 0,09516671 untuk nilai Mean Absolute Percentage Error (MAPE).

3. Berdasarkan hasil akurasi, maka teknik Hybrid lebih akurat dibandingkan teknik Backpropagation, karena memiliki nilai akurasi kesalahan prediksi yang lebih kecil berdasarkan nilai Mean Absolute Deviation (MAD) dan Mean Absolute Percentage Error (MAPE).

B. Implikasi

Untuk kualitas penelitian yang lebih baik, maka hal - hal sebagai berikut perlu dilakukan :

1. Untuk hasil pengujian yang lebih baik, disarankan data uji yang digunakan jumlahnya diperbanyak.

2. Teknik analisa data yang digunakan, bisa dicoba dengan teknik yang lainnya untuk meningkatkan hasil akurasi yang lebih baik.

\section{DAFTAR PUSTAKA}

[1] Agustin, Maria, 2012, ” Penggunaan Jaringan Syaraf Tiruan Backpropagation Untuk Penerimaan Mahasiswa Baru Pada Jurusan Teknik Komputer Di Politeknik Negeri Sriwijaya”, Jurnal : Jurusan Teknik Komputer Politeknik Negeri Sriwijaya.

[2] Alven Safik Ritonga1, Suryo Atmojo, 2017, “ Pengembangan Model Jaringan Syaraf Tiruan Untuk Memprediksi Jumlah Mahasiswa Baru Di PTS Surabaya (Studi Kasus Universitas Wijaya Putra) “, Seminar Nasional Teknik Industri

[3] A. Rahman, A.G. Abdullah, dan D.L. Hakim, 2012, "Prakiraan Beban Puncak Jangka Panjang pada Sistem Kelistrikan Indonesia Menggunakan Algoritma Adaptive Neuro-Fuzzy Inference Sistem”, Electrans, Vol.11, No.2, 18 -26.

[4] Anugrah, 2012, "Perbandingan jaringan saraf tiruan Backpropagation dan metode deret berkala Box-Jenkins (ARIMA) sebagai metode peramalan", Jurnal: Jurusan Matematika Fakultas MIPA Universitas Negeri Semarang.

[5] Bagus, Fatkhurrozi, M. Aziz Muslim, Didik R. Santoso, 2012, "Penggunaan Artificial Neuro Fuzzy Inference Sistem (ANFIS) dalam Penentuan Status Aktivitas Gunung Merapi”, Jurnal EECCIS Vol. 6, No. 2.

[6] Candra, Dewi, Werdha, Wilubertha, Himawati, 2015, "Prediksi Tingkat Pengangguran Menggunakan Adaptif Neuro Fuzzy Inference System (ANFIS)", Konferensi Nasional Sistem \& Informatika.

[7] Gandhi, Ramadhona, Budi, Darma, Setiawan, Fitra A. Bachtiar, 2012, "Prediksi Produktivitas Padi Menggunakan Jaringan Syaraf Tiruan Backpropagation", Jurnal Pengembangan Teknologi Informasi dan Ilmu Komputer.

[8] Hanke, J.E., Wichern, D.W. 2015, “Business Forecasting “. Prentice Hall, New York.

[9] Linda, Puspa, 2015, "Peramalan Penjualan Produksi Teh Botol Sosro pada PT. Sinar Sosro Sumatera Bagian Utara Tahun 2014 dengan Metode Arima Box-Jenkins", Jurnal : Fakultas Matematika dan IPA Universitas Sumatera Utara

[10] Matonda, Arizona, Zakson, 2013, "Jaringan Syaraf Tiruan dengan Algoritma Backpropagation untuk Penentuan Kelulusan Sidang Skripsi”, Jakarta: Pelita Informatika Budi Darma.

[11] Noor, Azizah, Kusworo, Adi b, Achmad, Widodo, 2013,“ Metode Adaptive Neuro Fuzzy Inference System (ANFIS) untuk Prediksi Tingkat Layanan Jalan “,Jurnal Sistem Informasi Bisnis 03.

[12] Risa, Helilintar, Intan Nur Farida, 2018, “ Penerapan Algoritma K-Means Clustering Untuk Prediksi Prestasi Nilai Akademik Mahasiwa “, Jurnal Sains dan Informatika Volume 4, Nomor 2.

[13] Rohana, Tatang, 2012, “ Teknik Pengolahan Citra Dan Adaptive Neuro Fuzzy Inference System (ANFIS) Untuk Mendeteksi Cacat Keping Printed Circuit Board (PCB)” Jakarta.

[14] Siang, Jong Jek, 2005, “Jaringan Syaraf Tiruan dan Pemogramannya Menggunakan Matlab”. Yogyakarta: Andi Offset.

[15] Wanti, Rahayu1, 2017, “ Model Penentuan Guru Berprestasi Berbasis Adaptive Neuro Fuzzy Inference System (ANFIS), Jurnal Sisfotek Global 2088 - 1762 Vol. 7 No. 1.

[16] Wiwik, Anggraeni, 2012, “Aplikasi Jaringan Syaraf Tiruan Untuk Peramalan Permintaan Barang”, Jurnal: Jurusan Sistem Informasi, Institut Teknologi Sepuluh November.

[17] Widodo, P.P., Handayanto, R.T., 2012, “ Penerapan Soft Computing dengan matlab “, Bandung. 